https://doi.org/10.25312/2391-5137.14/2020_Olazt

\title{
Figurative meanings of lexemes of the thematic group "divine" in the creation of emotive evaluation in the Russian and Spanish languages (pragmalinguistic approach) $^{1}$
}

\begin{abstract}
This article considers the phenomenon of emotional assessment based on Russian and Spanish vocabulary (including slang), as well as phraseology. For the first time, a comprehensive semantic comparative study of the ways of forming and using evaluative units, reflecting the peculiarities of the perception of the linguistic pictures of the Spanish and Russian languages, has been carried out. The author analyzes the lexical and phraseological material, ways of representation in lexicographic practice, the reasons for the emergence of secondary evaluative meanings. The results obtained allow us to confirm the hypothesis that the belonging of the primary nominative meanings of lexical units to a specific FSH, in our case the "divine" group, leads to the emergence of secondary positive emotional evaluative semantics.

The commonality of norms governing the formation of positive assessments in Russian and Spanish was confirmed, which makes it possible to speak about the presence of a common model of evaluative semantics as a single system, as well as the absence of a fundamental difference in the figurative structure and methods of forming an evaluative nomination in Russian and Spanish, determined by the common Christian culture and civilization, as well as the common origin of languages.
\end{abstract}

Keywords: pragmalinguistics, Spanish, Russian, lexical and phraseological units, figurative meaning, emotional evaluation, FSG, "divinity", "angel", "God".

\footnotetext{
${ }^{1}$ This work was supported by the project "Disinformation and Aggressiveness in Social Media: Analyzing the Language" of the Spanish Ministry of Economics and Development.
} 
A highlighting approach to some semantic fields related to expressiveness and emotional evaluation does not require special clarification. Communicative goals, emotional conviction (Yakubinsky, 1986: 18) are studied in a variety of ways in relation to Russian and other languages. The specifics of pragmatic (as opposed to descriptive) meanings determine the special role of paradigmatic and syntagmatic characteristics. The patterns of using emotional-evaluative vocabulary with certain pragmatic goals are discussed. Pragmalinguistic scholarship is marginal in the Spanish linguistic tradition.

In my opinion, pragmatical analysis allows us to combine different approaches (semantics, lexical/vocabulary, grammatical: morphological y syntactical) in the frame of expressing special types of intention. In the Russian tradition this approach could be identified as "pragmalinguistics" (Kiseleva, 1978).

N.D. Arutyunova contends that "pragmatic meaning is revealed through syntax. The difference in the syntactic positions occupied by evaluative predicates, in turn, is associated with differences in the nature of those objects that they define" (Arutyunova, 1988: 7). This view is based on the juxtaposition of the identification function and the prediction function, among the syntagmatic features of the use of vocabulary with a positive emotional assessment, the most typical are the positions of vocative and predicate (Zaynuldinov, 2019).

\section{Hypothesis. FSG}

In the framework of pragmalinguistics (speech impact theory), L.A. Kiseleva contends that the criterion for classifying vocabulary as emotionally-evaluative units is the internal form. The markers that determine emotional evaluation, among others, include the presence of metaphorical imagery or imagery arising from the emphasized darkened motivation of semantics at the synchronous level.

The author shares the positions of linguists who recognize within the framework of the lexical system the existence of the opposition 'a synonymous series - a lexical-semantic group (LSG) - a lexical-semantic field' and including only one part of speech in the LSG. At the same time, the conditionality of the means of creating emotional-evaluative semantics by the thematic relevance of lexemes requires taking into account belonging to certain thematic groups (TG). This takes into account the thematic relevance of linguistic units as semantic complexes, which determines the nature and sign of emotional evaluation.

The specifics of emotional evaluative semantics determines a special approach to the selection of groups, which takes into account, along with primary nominative, secondary evaluation values, i.e. the principle of functional-communicative typology of pragmalinguistic units determines the foundations of groupings.

In this article, emotional-evaluative vocabulary is described within the framework of functional-semantic groups (FSG). The nominative primary meanings belong to a certain thematic group. This leads to the formation of a secondary emotional-evaluative value of a certain evaluative sign. Among the negative-evaluative units is the FSG "divine" (with figurative meanings of words angel, God, paradise, divine, derivative words from them and these components as part of phraseological units). 
The author suggests that the assignment of the primary nominative meanings of lexical units to a certain LTG (lexical-thematic group) or LPTG (lexical-phraseological thematic group, taking into account phraseological units) causes the appearance of a secondary emotional-evaluative semantics of a positive or negative order. Thus, a negative emotional evaluation can be reflected in FSG (functional-semantic groups) of "dirt", "emptiness", "diabolical", "black", "wooden", and a positive - in FSG of "heavenly", "brilliance", "divine", "light", "beautiful", "sweets".

This classification of FSG, combining lexical and phraseological units that express emotive evaluation (including general slang), is presented in a systematic form for the first time, although some observations on this subject can be found in a number of lexicological and phraseological studies, cultural and ethnographic works of V.I. Dal, A.A. Potebnia, A.S. Famintsyn, A.N. Afanasyev, A.M. Melerovich, V.M. Mokienko and others, where the thematic relevance to the FSG is not specifically mentioned, but where, in particular, some patterns of rethinking the primary semantics are proposed.

FSG "divine" is a group of lexical and phraseological units. Units with the components "angel" and "Good" exhibit all the typical patterns of the creation and functioning of emotional evaluation.

This factor has determined the structure of the main research part of this article.

\section{Purpose. Material}

The purpose of this article is to study the pragmatic aspect of semantics based on emotionally-evaluating Russian and Spanish vocabulary and phraseology, the primary meaning of lexical units or components of phraseological units of which relates to functional semantic groups (FSG) "divine". The scope of this article allows a consideration of only linguistic units with the components "angel" and "God", nevertheless, this limitation does not prevent more general conclusions.

The research methods include a comprehensive description, component, contextual and definitional analysis (within the framework of the pragmalinguistic approach), as well as comparative analysis of Russian and Spanish. The research material was taken from BAS and EMOS (Dictionary of Russian Emotionally Evaluating Vocabulary and Phraseology), created by the author, as well as explanatory and phraseological dictionaries of the Russian and Spanish languages.

The Russian part of FSG "divine" in our corps has more than 150 lexical and phraseological units, including units of general slang. The Spanish part of FSG "divine" includes more than 150 lexical and phraseological units, created on the basis of DRAE, DER, ELSOEZ, DFER.

The corpus of emotional-evaluative vocabulary created by the author (EMOS 20052020) allows one to determine the concept of this phenomenon and present some citations from the literature which reflect both paradigmatic and syntagmatic patterns of using language evaluative units, taking into account the unity of morphological and syntactic characteristics. 


\section{Components "angel", "angelic", "cherub", "cherubic" (ангел, ангелок, ангелочек, ангельский, херувим, херувимский; ángel, angelito, angélico, angelical; querub, querube, querubín)}

\subsection{Lexical units}

The nominative meanings of the words angel and angelic in Russian and Spanish almost coincide: ангел (angel) - '1. Supernatural being, messenger and doer of the will of God on Earth'; ангельский (angelic) - '1. Relating to an angel (1 meaning)' (БАС); ángel (angel) - '(messenger in Greek) 1. Heavenly spirit created by God. 2. Each of the heavenly spirits'; angelical (angelic) - 'angélico' (DER).

The typical signs of these spirits are highlighted: 'beautiful', 'kindness', 'innocent' and define with figurative meaning a stable comparison in Russian: как ангел (like an angel), also this fact does not appear in Russian or Spanish dictionaries.

Beautiful, like a heavenly angel, Like a demon, treacherous and evil. (Lermontov, Tamara); Andrei Petrovich, you are kind as an angel, she said. (Turgenev, On the eve).

A figurative positive meaning in Russian is realized in the function of the vocative form or the predicate: ангел (angel) - '3. fig. About somebody, who is the ideal of something, the best embodiment, personification of something (usually in the function of predicate)' (БАС).

\section{Vocative:}

Grandma spoke in a touching, gentle voice: - Come here, my friend, come, my angel.

(L. Tolstoy, Childhood).

Predicate:

- My Ulyana Petrovna is an angel ... she is a true Christian, unmercenary, gentle.

(Leskov, Bypassed).

Another variant to distinguish nominative and evaluative meaning is realized in the so called phenomenon of "actualization" when to the word angel are added some characteristic which also could be presented in the lexicographical description: ангел (angel) - 'of something, some kind of angel' (БАC):

I, the angel of meekness and beauty, received your letter. (Pushkin, Letter to Pushkina); [Lyudmila] with her downcast gaze, with her flaming cheeks seemed an angel of beauty and purity. (Zhukovsky, Three belts); Nastya is our local angel, said Nina Sergeevna. We all quarrelled here, only no one ever quarrelled with her. (Volodin, An incident that no one noticed).

The same comparison value (signs of 'meekness, serenity, beauty, youth' in an angel) thanks to use of lexical unit as an actualization mark creates the figurative meaning of the phrase (angel of meekness and beauty; an angel of beauty and purity; local angel).

An actualization mark could be the possessive pronoun my (less often our) that determines the emergence of stable pragmas of мой ангел (my angel), наш ангел (our angel) (БAC): 
- Yes, you are my dear angels, but your reasonable heads! (Shukshin, Maternal heart);

- What's wrong with you, what's wrong with you, my angel?

- Asked her husband. (Herzen, Who is to blame?).

The pragmalinguistic approach allows us to distinguish in both Russian and Spanish two different meanings expressing different types of positive emotional evaluation: an expression of admiration and an expression of affectionate attitude: ангел (angel) '1. noun, m. of what, predicate. Admiration, fig. About person as the embodiment of beauty, kindness. The angel of meekness. Angel of purity. Angel of innocence. 2. noun, $\mathrm{m}$. vocative. Cares, fig. Affectionate treatment, mainly to a beloved woman or to a child. Goodbye my angel.' (EMOS).

A similar meaning of meekness, patience, kindness, and beauty is realized in the adjective ангельский (angelic) - '2. Inherent to an angel (in 3 meaning); such as that of an angel. Angelic meekness. Angelic patience.' (БАС); ангельсий (angelic) - 'adj. Admiration, fig. Characterized by extreme meekness, tenderness, kindness; wonderful in its positive qualities. Angelic kindness. Angelic behaviour. Angelic character. Angelic patience. Angelic smile. Angelic voice.' (EMOS):

An angelic voice greeted me with her. I can't express the sweet feeling that has possessed me at this moment. (Pushkin, Captain's daughter). Knowing her (Verochka) angelic disposition, I'm sure she will forgive me. (Turgenev, Two friends).

In Spanish, as well as in Russian, the semantics of meekness, kindness and beauty are expressed in figurative meanings. A child's particular characteristic is highlighted: ángel (angel) - '2. pred. A man of angelic meekness, also kindness (about a child - an angel, a cherub)' (DER); ángel (angel) - '4. A person who assumes qualities characteristic of angels, namely kindness, beauty, and innocence' (DLE); angelical (angelic) - 'fig. Angelic' (DER), angélico (angelic) (DLE).

In Spanish, however, in the lexicographical description the difference between the figurative meaning on the basis of which phraseological unit is created (ángel (angel) '3. Elegance, sympathy, charm; Tiene mucho ángel - he/she is very charming' (DLE)) and another figurative meaning of a person (ángel (angel) - 4. Person in whom the qualities proper to angelic spirits are assumed, that is, goodness, beauty and innocence' (DLE)) can be observed.

In Russian the use of the diminutive suffix -ок in general can give both a diminutiveaffectionate and a diminutive meaning. In our case a nominative meaning coexists: ангелок (little angel) as one of little heavenly spirits (БАС) with another figurative evaluative meaning ангелок (little angel) - '2. fig. About somebody causing sympathy' (БAC) where the diminutive describes youth of age of evaluated person (usually a child):

- Well, Petya, let's say, is an angel without a halo, everyone will stroke him, and with Vasya, only his wallet is close. (Sanin, Seventy two degrees, below zero).

The sign 'child, young man, girl' (which probably came from the concept that initially in religion, a servant of God, a doer of his will and his messenger to people usually depicted as a winged lad, a young man (БАC) is manifested with other evaluative suffixes 
of expressing cares -очек and -чик: ангелочек (little angel) - '2. fig. About somebody causing sympathy', ангельчик (little angel) - 'Same as an angel '. (БАС):

[Vasilisa Peregrinovna:] Now your son, our angel, has come here. (A. Ostrovsky, Inmate); What kind of angel our Misha became, if you only saw him! (Chekhov, Live Commodity); A mother and a daughter walked towards me, a girl of about ten, pretty, like an angel. (Dostoevsky, Notes from the Dead House).

In Spanish, there is also a form with a diminutive suffix -ito: angelito (little angel) '1. Child of little age when appealing to his innocence' (DLE), which also has other meanings not connected with evaluative semantics: angelito (little angel) - '2. A recently passed away child' (DLE). In the Spanish lexicographical description we may see a phenomenon which also exists in Russian. Irony as a systematic transposition of positive evaluation determines the appearance of the meaning with negative content (Zainouldinov, 2007: 40): angelito (little angel) - '3. Person of doubtful intentions or of bad moral qualities.' (DLE).

In Spanish however with the augmentative suffix -ón appears the evaluative negative phrase: angelón de retablo (angel from the picture) - '1. Fat man. 2. Maypole.' (DFER).

It is curious that in Russian there is an adverb ангельски (angelically) - 'adverb. As an angel (in 3 meaning), like an angel' (БАС), in which only a figurative evaluation value is realized, there is no primary nominative semantics; ангельски (angelically) - 'adv. admiration fig. Remarkable in its positive qualities.'(EMOS):

[Lisa] was too angelically innocent to be able to bear all the responsibilities of her mother. (L. Tolstoy, War and Peace); Here is a river and a boat. Here he saw Varen$k a$ reflected in the water and angelically beautiful in that reflection. (Gorky, Varenka Olesova).

In Russian a separate group consists of linguistic units based on the lexeme cherubim, originally in Christianity denoting an angel belonging to one of the highest angelic faces. As in the case of the angel, in the figurative meaning the sign is updated 'of heavenly, extraordinary beauty': херувим (cherub) - 'obsolete. Admiration, fig. About an unusually beautiful person.' (EMOS):

- You look at me, who I am. Well, can I match such a cherub! (Saltykov-Shchedrin, Little things in life).

In the formation of the adjective, the semantics of beauty are also expressed: херувимский (cherubic) - '2. adj. Admiration, fig. Beautiful, angelic (about a man).' (EMOS)

There is no childish, cherubic breath of freshness, like Marfenka's. (Goncharov, Cliff),

The figurative meaning of adjective based on the redundancy of the attribute, can lead to the appearance of a negatively evaluative connotation: херувимский (cherubic) - '3. adj. Disapproved or irony, fig. Sugary (usually about a person's appearance)' . (EMOS)

Polovodov was simply embarrassed by trifles: uncle's unpleasantness, his cherubic appearance and the slimness of the whole figure. (Mamin-Sibiriak, Privalov millions). 
With the formation of the stable comparison, the semantics expands and the sign of kindness appears: как херувим (like a cherub) - 'obsolete. Admiration, fig. Very beautiful and very kind person.' (EMOS). As in the case of ангел (angel), when using a caressing diminutive, the beauty of a child is positively evaluated: херувим (cherub) - 'obsolete. Admiration, fig. About a beautiful child.' (EMOS):

- A young lady, my dear, here's this handsome graph, she said, just a black-browed cherub. (Tolstoy, Two hussars).

An adjective black-browed also could be described as a mark of actualization, it references the person, an object of evaluation, and not to the angel in its primary nominative meaning.

In Spanish tradition, however, the noun querubín (cherub) is not related to the higher face of angels: querubín (cherub) - '1. Each of the heavenly spirits' (DLE), but just like in Russian, the figurative meaning and stable comparisons express the semantics of extraordinary beauty: querubín (cherub) - '2. A man of extraordinary beauty" (DLE); Querube, querubín (cherub) - '2. Man of angelic beauty / about a child' (DER). A special attention should be paid to the high poetic style of using derivatives from this root: Querub, Querube (cherub) - 'Poetically; cherub”), Querúbico (cherub) - 'poetically; cherubim' (DLE).

\subsection{Phraseological units}

The same principle of the actualization of the secondary evaluative meaning determines the formation of evaluative phraseological units.

In Russian there are a number of language units with a figurative meaning (or in stable comparisons) based on the component angel with some markers (guardian, in the flesh, of kindness, of my soul, earthly):

ангел-хранитель (guardian angel) - “noun. M. Approved, fig. One who protects someone. Initially: an angel protecting a given person or a saint whose name the person bears.' (EMOS)':

(Romanenko-: You are not only the oldest member of the corps collective, but still our reliable guardian angel of the medical service. (Pavlenko, Happiness);

ангел во плоти (angel in the flesh) - 'lit., obsolete, fig. A meek, sensitive, immaculate man.'

Laugh, Nadya, joke! Drink from a golden bowl. The happiness of life is young. A sweet angel in the flesh! (Polezhaev, Nadenka);

ангел доброты (angel of kindness) - 'lit., obsolete, fig.. About a person who is distinguished by special kindness.';

ангел души моей (angel of my soul) - 'lit., obsolete. Affection, fig. In speech etiquette it is used in an affectionate address to someone.'

(Khlestakov@) Farewell, Anton Antonovich! Very obliged for your hospitality! Farewell, Anna Andreyevna! Farewell, angel of my soul, Marya Antonovna! (Gogol, Examiner); 
ангел земной (earthly angel) - 'lit., fig. About a person who is distinguished by holiness, righteousness, spirituality, purity and meekness.'

As we can see, in Russian there are many obsolete forms used in literature. In Spanish, however, the stylistic spectrum of use of phraseological units is more diverse, for example, the nominative stable combination: hacer el ángel (make an angel) - 'Make the angel jump' (DLE), the equivalent of the guardian angel: ángel custodio, ángel de guarda (guardian angel), evaluative expressions with negative connotation: ángel patudo (angel with paws) - 'col. A person who does not have the qualities of innocence and virtues attributed to him”) (DLE); 'the wolf in sheep's clothing' (DER); mal ángel (bad angel) - 'Boring person, bore' (DER); and evaluative expressions with positive connotation: tener (mucho) ángel (to have a lot of angel) - 'To be (very) cute, charming, charming' (DER); onar con los ángeles (to sleep with angels) (DLE).

Both in Spanish and in Russian there are equivalents: pasar un ángel (un angel passed) - 'The expression is used when a moment of complete silence arises during a conversation’ (DLE) cf. ангел пролетел (angel flew) in Russian.

\section{Components "God", "goddess", "deity", "divinity", "divine", "divinely" (Бог, богиня, божество, божественность, божественный, божественно; Dios, diosa, deidad, divinidad, divino, divinamente)}

\subsection{Lexical units}

With the full equivalent of the primary nominative meaning in Russian and Spanish: Бог (God) (with a capital letter in Russian (with reservations) and Spanish) - ' 1 . According to religious beliefs - the creator of the Universe, all that exists; the highest mind that rules the world. 2. With polytheism - one of the supernatural beings that control some part of the world' (БАC); Dios (God) - '1. Supreme being that in monotheistic religions is considered the maker of the universe. 2. Deity to which the various religions give or have worshiped.' (DLE). However in the Russian language there is a wide scale of varieties of secondary figurative meanings reflected in lexicographical description: Бог (God) - '4. fig. About a powerful man who has power over other people (usually in the function of a predicate) // fig. About a man of extraordinary creative talent; genius' (БАС):

Everyone is afraid of grandfather: grandfather is our sovereign and god. (Gladkov, A Tale of Childhood). [Salieri:] What a depth! What courage and what harmony! You, Mozart, a god, you yourself don't know. (Pushkin, Mozart and Salieri).

As in the case of angel, there is a figurative meaning of Бог (God) - 'of something, some kind of God' (БАС) and a typical evaluative transposition to irony or joke:

It would be more correct to listen to the words of Mozart, this god of music. (Selvinsky, I will talk about poems); At the hearth of the family ... I find love, affection, care and, 
of course, an excellent table. I have a cook, a chef, a culinary god! (Shugaev, Peter and Paul).

On the base of this meaning created from a stable comparison appears another figurative meaning with less descriptive and more pragmatic characteristics: Бог (God) - '5. fig. On the subject of worship, admiration; idol (usually in the function of the predicate) (БАC); Бог (God) - 'noun m. (obsolete, lit.) Admiration, fig. The subject of worship, adoration. Music is his god. This girl is a God for him.' (EMOS):

I have no other god but painting. (Kaverin, In front of the mirror); Architecture was the god of Valitsky, the only thing he bowed to. (Chakovsky, Blockade).

Similar figurative meanings (a sign of beauty and a general evaluation of the expression of admiration) also arise in the derivative words богиня (goddess) - ' 2 . f. fig. About the beloved, adored woman' (БАС); богиня (goddess) - 'noun f. admiration fig. About a beautiful and majestic woman, as well as (obsolete) about a woman as an object of love.' (EMOS):

I am your slave, he exclaimed, I am at your feet, you are my lord, my goddess. (Turgenev, Calm); My goddesses! What do you? Where are you? Are you the same? Other virgins, having replaced, have not swept you up? (Pushkin, Eugene Onegin); Grushnitsky stood in the crowd of people... without taking his eyes off his goddess. (Lermontov, Princess Mary).

Very similar characteristics are represented by lexical unit божество (deity) - '2. fig. About somebody as an object of admiration, worship, adoration; idol (usually as a predicate)'; божество (deity) - 'noun admiration fig. The subject of adoration, adoration. She is his deity.' (EMOS):

(Olga) is a deity, with this sweet babble, with this graceful, white face, thin, delicate neck. (Goncharov, Oblomov); A woman of the Middle Ages is a deity: for her tournaments, for her spears break. (Gogol, On the Middle Ages); I had two deities: Chopin and Scriabin. (Rekemchuk, Boys).

It is curious that the attachment of the diminutive suffix to the base God, which does not allow the concept of diminution, makes impossible a figurative meaning as in the case of the angel, but gives an affectionate meaning: боженька (God with diminutive) - 'Cares form to God (in 1 meaning)'.

The formation of secondary evaluative meanings in the adjective божественный (divine) and the adverb божественно (divinely) is interesting. The adjective божественный (divine) in both languages in Russian and Spanish has primary nominative and secondary figurative evaluative meanings: божественный (divine) - ' 1 . Refers to a deity (1 meaning). // Being a deity. // Coming from a deity, god (in 1 and 2 meanings) given to them by God. 3. Obsolete, connected with religion; church)' (БАС) on the one hand, and божественный (divine) - '2. Such as that of God, extraordinary in manifestation power. Divine compassion. Divine exaggeration.' (БАС); божественный (divine) - 'adj. Admiration, fig. Charming, lovely, marvellous. Divine voice.' (EMOS); divino (divine) '3. Very excellent, extraordinarily exquisite' (DRAE); divino (divine) - '2. Gorgeous, amazing' (DER): 
And the divine leg glides on the carpet, floats. (Lermontov, Demon); It was just as solemnly breathing in the sky, and night, the divine night, majestically burned out. (Gogol, May Night).

But the short form of this adjective in Russian has only an evaluative meaning, the same as an adverb or interjection with semantics of admiration: божественно (divinely) 'adverb, also as interjection. Admiration. Charming, marvellous.' (EMOS):

[Semyon:] Nice! Divine! Perfectly! Dasha! My life! [Dasha:] Semyon! Are you crazy! (Krylov, Lesson to daughters); He played divinely! What a tone, what a force, what a fullness! (A. Borodin, My memories of Liszt); She seemed to me divinely beautiful in spring dusk. (Korovin, Recalls).

\subsection{Phraseological units}

The absence of figurative meanings in Spanish for the lexical units with component of Dios is compensated by a significant number of phraseological units, stable comparisons and exclamations. Most of them coincide with the Russian equivalents (probably, due to the commonality of Christian culture).

The scope of this article does not allow a presentation of extensive material on phraseology with the component God both in Russian and in Spanish, which should become the topic of a special study. Here we will focus on the specific meanings of the Spanish language which have not received sufficient coverage in linguistic scholarship.

A considerable group are represented phraseological units with comparison God and devil:

congraciarse con Dios y con el diablo (serve both God and the devil); no creer ni en Dios ni en diablo (do not believe in the God or in the devil); no servir a Dios ni al diablo uno, una cosa (not serve neither for God nor for the devil) - 'It's not good at anything, to be worthless'; no temer uno ni al Dos ni al diablo (be fearless in front of God or devil); in Russian ни богу свечка, ни чёрту кочерга (neither a candle for a God nor a fire iron for the devil) - 'Disapproval. Unsuitable, useless person.' (EMOS).

The positive connotation of God determines positive meanings of phraseological units like

Monks live behind their stone walls like a god in his bosom. Food is his own, wine is his most excellent, nuns, charming in their way ... gold, and, moreover, not a little, their own. (Druta, White Church); - He took care of me. He didn't force me to do anything. We ate in a restaurant. Champagne, chocolate ... Yes, I lived behind Vitaly, like God in his bosom. (Ukhanov, Nefertiti from Klyuchevka).

Following the same line, to be against God is a bad idea in the language picture of Christian culture:

ser una cosa un contra Dios: es un contra Dios (to be against God) - 'Worse than ever, very badly'; no tener Dios por dónde cogerle a uno: no tiene Dios por dónde cogerle (God has nothing to grab onto) - 'Villain, bastard'.

Among mismatches in Spanish (and evaluative meaning unmotivated by the internal form of the phrase), one can note the concepts: 
1. "a large amount"

Dios y su madre (God and the Virgin) - 'fig. Huge amount of something'; de Dios (from God) - 'Strong, a lot'; llueve de Dios (raining from God) - 'Raining a lot'; comerse a Dios por las patas (eat a God with legs) - 'Be a glutton'; necesitar (de) (necesitarse) Dios y ayuda (need God and help) - 'Cost a lot of work' (DFER); costar Dios y ayuda (cost God and help) - 'expressive. Need a lot of effort, to be difficult (ELSOEZ);

2. "bad end"

como dios quiera (as God wants) - 'Badly, somehow'; acabar como Dios quier acabar Dios sabe cómo (end as God wants, as God knows) - 'Bad ending'; ¡A Dios mi dinero! (goodbye my money) - '1. Cried my money. 2. My business is bad, write is gone' (DFER).

\section{Sensitization of evaluative semantics}

A typical characteristic of the use of emotionally-evaluative vocabulary and phraseology (at the phraseological level, within the context of the utterance) is sensitization (сенсибилизация in Russian; Kiseleva, 1978: 114), an increase in the intensity of the illocutionary effect. Given the fact that phraseological units by their nature are miniutterances (at least etymologically), there may be cases where definitions of supporting components, whose lexical semantics already have a certain emotive appraisal, naturally enhance the illocutionary effect of exposure:

- My angel! My treasure! - said Kalinovich, kissing her [Nastenka]. (Pisemsky,

A Thousand Souls); I foresaw that I would catch Marya Ivanovna alone ... I hugged her. Farewell, $\boldsymbol{m y}$ angel, $\boldsymbol{m y}$ dear, $\boldsymbol{m y}$ desired. (Pushkin, Captain's daughter); - What kind of angel is this Adochka, what a delight!" (Turgenev, Noble Nest); [Warden:] Your home is Eden, and you yourself are a goddess! (Gorky, Barbarians).

\section{Nominal-evaluative and self-evaluative meanings}

From the works of L.A. Kiseleva, who distinguishes between nominative, deictic, nomie native-evaluative, determinative, emotional meaning, in Russian semantics the scheme of lexical meaning is generalized according to its composition with a greater or lesser degree of denotativeness (nominative descriptive component) and connotativeness (pragmatical component). Following this approach, the vast majority of FSG language units of "divine" characterizing a person, both in Russian and in Spanish, equally combine these components.

The author highlights the pattern of development of a self-evaluative meanings, when the range of evaluated objects is expanded and the emotional evaluative semantics dominate: ангел (angel) - '1. noun, m. of what, predicate. Admiration, fig. About person as the embodiment of beauty, kindness. The angel of meekness. Angel of purity. Angel of innocence. 2. noun, m. vocative. Cares, fig. Affectionate treatment, mainly to a beloved woman or to a child. Goodbye my angel.' (EMOS); divino (divine) - '3. Very excellent, 
extraordinarily exquisite' (DRAE); Бог (God) - '5. fig. On the subject of worship, admiration; idol (usually in the function of the predicate) (БАС). These lexemes angel, divine, God in figurative meanings are used in the same way as quasi symbols or affective pragma words:

1. expansion of objects of evaluation:

He played divinely! What a tone, what a force, what a fullness! (A. Borodin, My memories of Liszt); [Kartashov:] She [Nina] is divine! Everything is perfect in her! Face, eyes, figure! (Sofronov, Million for a smile); Everything in her is angelic: and her face, and the miniature of her stature, and the wonderful kindness of her heart. (Druzhinin, Polinka Saks);

2. affective pragma words:

I am your slave, he exclaimed, I am at your feet, you are my lord, my goddess. (Turgenev, Calm); [Ivanushko] grabbed her hands and kissed, said: I love, crazy, goddess! (A.N. Tolstoy, Egor Abozov); [Strekalov:] Tinochka! (Kneels before her.) My deity. (Lavrentiev, The Last Legend).

Opportunities of use of lexical and phraseological units appear to characterize the addressee, object, feature, and situation in general: божественно (divinely) - 'adverb, also as interjection. Admiration. Charming, marvellous.' (EMOS):

[Semyon:] Nice! Divine! Perfectly! Dasha! My life! (Krylov, Lesson to daughters);

- You shine, just like a birthday boy. - I am the birthday boy, smiled Romashov. -

Yes? Divine. (Kuprin, Duel); [Michelle:] (gives him a plate with an ear) Well, how?

[Alyosha:] Yummy. [Zimina:] Divine. (Arbuzov, Happy days of an unhappy person).

Actually, they resemble the evaluative-emotional interjections: Hurrah! Bravo!

\section{Transposition of evaluative semantics. Irony}

By emotional-evaluative transposition, we mean "the use of emotionally-evaluative words with an evaluative sign opposite to their usual emotional evaluation" (Kiseleva 1978: 130). Our research has shown that the collision of negative-evaluative intention with words with a positive emotional evaluation generates irony (Kiseleva, 1978: 120): херувимский (cherubic) - '3. adj. Disapproved or irony, fig. Sugary (usually about a person's appearance)'. (EMOS) Polovodov was simply embarrassed by trifles: uncle's unpleasantness, his cherubic appearance and the slimness of the whole figure. (Mamin-Sibiriak, Privalov millions); ser uno como Dios, que todo lo adivina (to be like an omniscient God) - 'iron. To be slow-witted, incongruous' (DFER); ангел-хранитель (guardian angel) My blue-eyed guardian angel, why are you looking at me with such sad dismay? - Krymov wanted to say ironically, guessing what worried Anatoly Petrovich. (Bondarev, Game). 


\section{Conclusion}

This article confirm the hypothesis that the belonging of the primary nominative values of lexical units to a specific FSG, in our case, the "divinity" group, leads to the appearance of a secondary positive emotional evaluation semantics.

In both Russian and Spanish, the vast majority of secondary figurative meanings of both vocabulary of this group express an expressive positive emotional evaluation. Most often, in the secondary evaluative meanings of both Russian and Spanish language units of the FSG "divinity", the semantics of "beauty, kindness, purity" is realized.

The phenomenon of sensitization is clearly expressed as an enhancement of the effect of exposure as well as the expression of irony as a systematical evaluative transposition. The dominant type of value is nominative evaluative, however, there is a desire to express general evaluative semantics, the extreme case of which are quasi symbols and interjections.

Our material demonstrates the prevalence of the number of Russian figurative evaluative meanings compared to Spanish, meanwhile on the level of phraseological units the number of units is more or less the same. In Spanish there is more negative and varied emotional evaluation of phraseological units with components of FSG "divine". In Russian the positive evaluation is more stable and permanent. However these confirmations requires more extensive research.

It can be summarized that the evaluation units can be used in vocative, predicate, and application position, (never acting in the role of the 'first presentation' of the subject without previous concretise marks), accompanied by the necessary actualization marks of the evaluation semantics, as well as in comparative constructions.

It should be noted that the norms governing the formation of positive evaluations in Russian and Spanish are common, confirming the existence of a common model of evaluative semantics as a single system, as well as the absence of a fundamental difference in the figurative structure and methods of forming an evaluation nomination in Russian and Spanish, determined by the common framework of Christian culture and civilization and common origin of languages.

Of course, the proposed analysis is not an exhaustive study of the syntagmatic aspect of the functioning of emotionally-evaluative vocabulary, but nevertheless, the identified semantic patterns can be used in the development of concepts of linguoculturology and stylistics, as well as in lexicographic practice and teaching Russian as a foreign language.

\section{References}

Arutyunova N.D. (1988), Tipy jazykovykh znachenij: Ocenka. Sobytie. Fakt. [Type of Language Meanings: Evaluation. Event. Fact.], Nauka, Moscow.

Carbonell Basset D. (2000), Gran diccionario del argot ELSOEZ [Big Dictionary of Slang], Larousse, Barcelona.

Diccionario de la lengua española, Real academia española DRAE (2001) [Dictionary of Spanish Language], Espasa Calpe, Madrid. 
Ispano-russkij frazeologicheskij slovar: 3000 frazeologicheskih edinic DFER (1985) [Dictionary of Spanish/Russian Phraseology], E.I. Levintova (ed.), Russky Jazyk, Moscow.

Kiseleva L.A. (1978), Voprosy teorii rechevogo vozdejstvija [Problems of Theory of Verbal Persuasion], Izdatelstvo LGU, Leningrad.

Sadikov A., Narumov B. (1998), Diccionario español-ruso del uso moderno DER [Russian/ Spanish Dictionary], Russki Yazyk, Moscow.

Slovar sovremenogo russkogo literaturnogo jazyka БАС (1948-1965) [Dictionary of contemporary Russian language], Nauka, Moscow-Leningrad.

Yakubinsky L.P. (1986), Izbrannye raboty: Jazyk i ego funkcionirovanie [Selected works: Language and Use], Moscow.

Zaynuldinov A.A. (2005-2020), Slovar russkoj emocionalno-ocenochnoj leksiki i frazeologii EMOS [Dictionary of Russian lexical and phraseological units with emotional evaluation], Universitat de Barcelona, Barcelona.

Zainouldinov A. (2007), Emocionalnaja ocenochnost russkoj leksiki i frazeologii (opyt pragmalimgvisticheskogo slovaria) [Emotional evaluation of Russian vocabulary and phraseology (attempt of the pragmalinguistic dictionary)], "Russian Language Journal ", nr 57, 29-42.

Zaynuldinov A.A. (2019), Sintagmaticheskie osobennosti funkcionirovanija russkikh ekspressivnykh jazykovykh edinic (na material leksiki s polozhitelnoj emocionalnoj ocenkoj) [Syntagmatic features of the functioning of Russian expressive language units (based on vocabulary with a positive emotional evaluation)], "Slavica Wratislaviensia", nr CLXIX, 81-88.

\section{Streszczenie \\ Znaczenia przenośne leksemów grupy tematycznej «boskie» w tworzeniu emocjonalnego wartościowania języka rosyjskiego i hiszpańskiego (ujęcie pragmalinwistyczne)}

Niniejszy artykuł poświęcony jest zbadaniu fenomenu oceny emocjonalnej na materiale słownictwa rosyjskiego i hiszpańskiego (z uwzględnieniem slangu) oraz frazeologii. Po raz pierwszy dokonano kompleksowej semantycznej analizy porównawczej sposobów powstawania i wykorzystania jednostek wartościujących, odzwierciedlającej swoistość percepcji kategorii językowych obydwu języków. Autor analizuje materiał leksykalny i frazeologiczny, sposoby prezentacji w praktyce leksykograficznej, przyczyny powstawania wtórnych znaczeń oceniających. Otrzymane wyniki potwierdzają hipotezę, zgodnie z którą przynależność pierwotnych znaczeń nominatywnych jednostek leksykalnych do konkretnej grupy frazeologiczno-semantycznej (GFS), w naszym przypadku grupy tematycznej «boski», prowadzi do powstawania wtórnej pozytywnej emotywnej semantyki oceniającej.

Podkreślono wspólność norm regulujących formowanie się ocen pozytywnych w języku rosyjskim i hiszpańskim, co pozwala konstatować istnienie ogólnego modelu semantyki wartościującej jako jednolitego systemu oraz brak pryncypialnej różnicy struktury obrazowej i metod formowania nominacji oceniającej w języku rosyjskim i hiszpańskim, będącej wynikiem wspólności kultury chrześcijańskiej, jak również wspólnego pochodzenia obydwu języków.

Słowa kluczowe: pragmalingwistyka, język rosyjski, język hiszpański, jednostki leksykalne i frazeologiczne, znaczenie przenośne, ocena emocjonalna, GFS, «boskość», «anioł», «Bóg» 